\title{
Addenda to the lichen flora of the Ticino river valley (western Po Plain, Italy)
}

\author{
Gabriele Gheza
}

\begin{abstract}
The Ticino river valley is a focal area for biodiversity in the western Po Plain (Northern Italy). Lichens have been collected by the author from 91 sites in the period 2011-2017. These collections and the few literature data published in the last decade have been summarized. Twenty-eight species ( 15 terricolous, 5 epiphytic, 3 lignicolous, 3 saxicolous, 1 epiphytic and lignicolous, 1 terricolous and epiphytic), mostly belonging to genus Cladonia, are reported here as addenda to the floristic list published 15 years ago by the Lombardy Ticino Park, which included 123 species. Many of the newly recorded species are interesting under a conservation or biogeographical standpoint.
\end{abstract}

Key words: Calluna heathlands, Cladonia, dry grasslands, floristics, lichen diversity, macrolichens, planitial woods.

Riassunto - Aggiunte alla flora lichenica della Valle del Ticino (Pianura Padana Occidentale, Italia).

La Valle del Ticino è un'area fondamentale per la biodiversità nella Pianura Padana occidentale. L'autore ha raccolto licheni in 91 siti nel periodo 2011-2017. Queste raccolte vengono di seguito riassunte insieme ai pochi dati bibliografici pubblicati nell'ultimo decennio. Ventotto specie (15 terricole, 5 epifite, 3 lignicole, 3 sassicole, 1 epifita e lignicola, 1 terricola ed epifita), per lo più appartenenti al genere Cladonia, sono qui riportate come aggiunte alla lista floristica pubblicata 15 anni fa dal Parco del Ticino Lombardo, che comprendeva 123 specie. Molte delle nuove specie rinvenute sono interessanti dal punto di vista conservazionistico o biogeografico.

Parole chiave: brughiere a Calluna, Cladonia, praterie aride, floristica, diversità lichenica, macrolicheni, boschi planiziali.

\section{INTRODUCTION}

The Ticino river is one of the most important rivers of Northern Italy, its valley being one of the most wellpreserved and biodiverse areas of the Po Plain (Furlanetto, 2002), the most anthropized and polluted area of Italy (World Health Organization, 2016).

Section of Landscape Ecology, Department of Earth and Evironmental Sciences, University of Pavia, Via S. Epifanio 14, 27100 Pavia, Italia.

E-mail: gheza.gabriele@gmail.com

(C) 2018 Gabriele Gheza

Received: 28 November 2017

Accepted for publication: 26 February 2018
The study of the lichen flora of the Ticino river valley began with Biroli (1808), who studied the western side in the surroundings of Novara. The first contribution for the eastern side is due to Cozzi (1917), who studied lichens in a rather wide area between Gallarate and Lonate Pozzolo, which at that time was covered with $\mathrm{Cal}$ luna heathlands and mixed broadleaved woods. After that, only few terricolous lichens found in the "Gallarate heathland" were cited by Giacomini (1958) in a phytosociological paper.

Studies focused on epiphytic lichens took place in the late 1990s for biomonitoring projects. From the first study, carried out in 1994 (Casarini et al., 1995), derived a first checklist of epiphytic lichens of the Lombardy Ticino Natural Park (Roella, 1999). A second study took place in 1999 (Furlanetto et al., 2000). Furthermore, some epiphytic and saxicolous lichens were recorded in the city of Pavia, which is located within both the river valley and the Park, respectively by Casarini et al., (1994) and Rigamonti et al. (2007).

With the checklists by Valcuvia Passadore et al. (2002 a,b), which included lichens from all substrates, the knowledge rose to a higher level. However, this fundamental work did not take into account some older literature (i.e. Cozzi, 1917; Giacomini, 1958) and the sampling effort for the new surveys was rather scarce if compared to the extent of the Park and of the river valley.

The most recent studies focused on terricolous lichens, which have been rather well surveyed under the floristic standpoint (Gheza, 2015; Ravera et al., 2016, 2017a,b; Gheza et al., 2018) and, partly, under a phytosociological perspective (Gheza et al., 2016). Terricolous lichens were rather neglected in the Po Plain (Gheza, 2015), but these studies showed that several areas with habitats of conservation value host lichen species of conservation and biogeographical interest, and even two species never found before in Italy (Gheza et al., 2018).

The aim of this paper is to update the lichen flora of the Ticino river valley reporting all the species found for the first time or rediscovered in the area after the study by Valcuvia Passadore et al. (2002a, b), summarizing literature records and unpublished personal collections of the author carried out in the period 2011-2017. Particularly, the records of the 28 species which are new to the area are given in detail. 


\section{MATERIALS AND METHODS}

\section{Study area}

The Ticino river valley lies at the boundary between Lombardy and Piedmont, between the southern end of the Lake Maggiore (Sesto Calende, $198 \mathrm{~m}$ ) and the confluence of the Ticino with the Po river (Ponte della Becca near Pavia, $53 \mathrm{~m}$ ), for a length of about $110 \mathrm{~km}$.

The whole rivercourse south of Lake Maggiore is included within two very important protected areas. The Lombardy Park (Parco Naturale Lombardo della Valle del Ticino) includes the eastern part, from Lake Maggiore to Cassolnovo and both sides downrun there to the confluence with the Po river, south of Pavia. The Lombardy Park includes 8 Sites of Community Importance (IT2010010 Brughiera del Vigano; IT2010012 Brughiera del Dosso; IT2030013 Ansa di Castelnovate; IT2010014 Turbigaccio, Boschi di Castelletto e Lanca di Bernate; IT2050005 Boschi della Fagiana; IT2080014 Boschi Siro Negri e Moriano; IT2080015 San Massimo; IT2080016 Boschi del Vignolo) and extends through 3 Provinces (Varese, Milano, Pavia). The Piedmont Park (Parco Naturale della Valle del Ticino Piemontese) includes all the western part from Lake Maggiore to the boundary with Lombardy beetween Cerano (Novara) and Cassolnovo (Pavia). The whole Park is a Site of Community Importance (IT1150001 Valle del Ticino) included in the province of Novara.

The bioclimate of the Ticino river valley is temperatecontinental in the central-southern part and temperate-oceanic in the northern part (Rivas-Martìnez et al., 2004).

Geological substrates are composed of mainly acidic sediments of the Holocene (pebbles, gravels and sands) dated to the recent Alluvium, while the surrounding substrates are referable to the "fundamental level of the plain" of the Pleistocene (D'Alessio \& Comolli, 1996).

The natural and seminatural areas are mostly covered by woodlands, which include xero- or mesophilous woods dominated by Quercus robur L. (Natura 2000 Habitats $9160,9190)$ and more hygrophilous mixed woods with Alnus glutinosa (L.) Gaertn., Fraxinus excelsior L., Ulmus minor Mill. and Salix alba L. (Habitats 91E0, 91F0). Residuals of Castanea sativa Mill. groves (Habitat 9260) are found in the northwestern part. In several localities, allochthonous pine groves are found as residuals of artificial plantations. Fragments of Calluna vulgaris (L.) Hull heathlands (Habitat 4030) are still found in the northern part of the river valley. Among herbaceous vegetation, the most valuable habitats are hygrophilous tall herb fringes (Habitat 6430), lowland hay meadows (Habitat 6510) and pioneer dry grasslands attributable to the Corynephorion Klika 1931 (Habitat 2330) and the Thero-Airion Tüxen ex Oberdorfer 1957 (Habitat 6210). Humid habitats are widespread, including oligotrophic (Habitat 3130) and eutrophic (Habitat 3150) backwater plant communities, running water communities of the Ranunculion fluitantis Neuhäusl 1959 (Habitat 3260) and vegetation of muddy river banks (Habitat 3270). Agricultural areas include fields cultivated with corn, wheat (in the northern part) and rice (in the central-southern part) and poplar plantations. Widespread in many habitats are some invasive woody species, i.e. Ailanthus altissima (Mill.) Swingle,
Prunus serotina Ehrh. and Robinia pseudoacacia L., which often form monospecific groves in areas with high human impact.

\section{Sampling sites}

Overall, 91 sites (65 in the Lombardy Park and 26 in the Piedmont Park) have been considered for single or repeated lichen surveys by the author in the period 20112017 , not only in the proper river valley but also on the fluvial terraces at its edges. Only the 27 sampling sites in which the new species were collected by the author (21 in the Lombardy Park and 6 in the Piedmont Park) are listed below, from north to south, with the name of the collection locality, the municipality, the province and region, the coordinates (in the UTM WGS84 system), the altitude above the sea level and the habitat type in which the specimens were collected.

All the available residuals of those habitats hosting terricolous lichens - dry grasslands and Calluna heathlands - have been surveyed thoroughly, increasing the number of sites in respect to those surveyed by Gheza (2015). Also several sites in well-preserved woods, more or less homogeneously distributed along the river valley, have been surveyed, and some agricultural areas have been considered too, in order to collect also epiphytic species from various trees. Several records have however an occasional character, because a systematic and exhaustive survey of the entire area has not yet been realized at present.

1. Brughiera del Vigano, Golasecca (Varese, Lombardy), 32T 473550.5060659, 270-275 m, mixed wood dominated by allochtonous Pinus sp. and Quercus robur.

2. Surroundings of Cascina Casone, Pombia (Novara, Piedmont), 32T 475605.5054239, 170-175 m, dry grasslands (Thero-Airion and Corynephorion).

3. Baraggia di Pombia, Pombia (Novara, Piedmont), 32T 473786.5055073, 180-183 m, mature dry Calluna heathland.

4. Ansa di Castelnovate, Vizzola Ticino (Varese, Lombardy), 32T 473965.5052551, 160-165 m, dry grasslands (Thero-Airion and Corynephorion).

5. Barbelera, Oleggio (Novara, Piedmont), $32 \mathrm{~T}$ 474883.5051775, 161-163 m, dry grasslands (TheroAirion and Corynephorion).

6. Marcetto, Oleggio (Novara, Piedmont), 32T 475076.5051299, 160-162 m, dry grasslands (TheroAirion and Corynephorion).

7. Bosco di Tornavento (northern sector), Lonate Pozzolo (Varese, Lombardy), 32T 478431.5050149, 218-222 $\mathrm{m}$, mixed broadleaf wood dominated by Quercus robur.

8. Brughiera di Tornavento, Lonate Pozzolo (Varese, Lombardy), 32T 478268.5049320, 200-202 m, open dry Calluna heathland.

9. Bosco di Tornavento (southern sector), Lonate Pozzolo (Varese, Lombardy), 32T 478617.5048757, 198-200 $\mathrm{m}$, mixed wood with Quercus robur, Pinus sp. and Robinia pseudoacacia.

10. Abandoned airfield "La Promessa" (northern sector), Lonate Pozzolo (Varese, Lombardy), 32T 
479079.5046631, 189 m, patch of open dry Calluna heathland.

11. Abandoned airfield "La Promessa" (western sector), Lonate Pozzolo (Varese, Lombardy), 32T $478613.5046423,187-188 \mathrm{~m}$, small patch of open dry Calluna heathland.

12. Abandoned airfield "La Promessa", Lonate Pozzolo (Varese, Lombardy), 32T 479289.5046158, 185-187 $\mathrm{m}$, dry grasslands (Thero-Airion).

13. Turbigaccio, Lonate Pozzolo (Varese, Lombardy), 32T 476213.5047261, $145 \mathrm{~m}$, dry grasslands (TheroAirion and Corynephorion).

14. Tenuta Bornago, Cameri (Novara, Piedmont), 32T 476709.5044341, 140-145 m, dry grasslands (TheroAirion and Corynephorion).

15. Surroundings of Cascina Rossa, Bernate Ticino (Milano, Lombardy), 32T 484074.5035048, 117 m, dry grassland (Thero-Airion).

16. Tenuta La Fagiana, Pontevecchio di Magenta (Milano, Lombardy), 32T 486444.5030677, 105-110 m, open Quercus robur wood.

17. Tenuta La Fagiana, Pontevecchio di Magenta (Milano, Lombardy), 32T 486316.5030625, 107-109 m, dry grasslands (Thero-Airion).

18. Surroundings of Villa Giulia, Cerano (Novara, Piedmont), 32T 487041.5027334, 99-103 m, dry grasslands (Thero-Airion).

19. Bosco del Modrone, Sforzesca, Vigevano (Pavia, Lombardy), 32T 494909.5015667, 76 m, dry grassland (Thero-Airion) with oak trees, logs and stumps.

20. Bosco della Ghisolfa, Sforzesca, Vigevano (Pavia, Lombardy), 32T 494163.5014115, 87-89 m, mixed broadleaf wood dominated by Quercus robur.

21. Bosco Ronchi, Sforzesca, Vigevano (Pavia, Lombardy), 32T 495844.5013587, 72-76 m, dry grasslands (Thero-Airion).

22. Bosco Ronchi, Sforzesca, Vigevano (Pavia, Lombardy), 32T 496308.5013294, 72-76 m, mixed broadleaf wood dominated by Quercus robur.

23. Butterfly Trail of Molino d'Isella, Gambolò (Pavia, Lombardy), 32T 496122.5012667, 73 m, ruderal dry grassland.

24. Torre d'Isola(Pavia, Lombardy), 32T 508504.5005975, $84 \mathrm{~m}$, poplar plantation.

25. Centro Ippico di Pavia (Pavia, Lombardy), 32T $510212.5003452,71 \mathrm{~m}$, poplar and walnut plantation.

26. San Martino Siccomario (Pavia, Lombardy), 32T 513524.5001696, $70 \mathrm{~m}$, poplar plantation.

27. San Martino Siccomario (Pavia, Lombardy), 32T $511365.5000769,77 \mathrm{~m}$, tree-lined avenue in the inhabited center.

\section{Lichen sampling and other data sources}

Specimens were collected on the field in all the possible occasions in a total of 243 field inspections which included all the 91 sites at least once for each site. Furthermore, all the literature records published after Valcuvia Passadore et al. (2002 b) have been considered. Not all the species in the floristic list reported below are actually new for the study area: some of them are reported in older papers but were overlooked since the early $20^{\text {th }}$ century, while two other (i.e. Cladonia caespiticia, Normandina pulchella) were not reported by Valcuvia Passadore et al. (2002 b) in spite that they had been recorded in the previous floristic list by Roella (1999).

Overall, 102 records (45 unpublished and 57 from literature) are reported in the floristic list below. For each species, every single record includes: the number referred to the sampling site, the substrate on which the specimen was collected, and the sources of the record. Each species is shortly discussed in regard to historical records and current distribution.

Abbreviations used for herbaria and literature in the floristic list and in Appendix 2: B08: Biroli (1808); C17: Cozzi (1917); GG: herbarium Gheza; GG15: Gheza (2015); GA18: Gheza et al. (2018); G58: Giacomini (1958); RA16: Ravera et al. (2016); RA17a: Ravera et al. (2017 a); RA17b: Ravera et al. (2017 b); RI07: Rigamonti et al. (2007).

\section{RESULTS AND DISCUSSION}

Overall, about 500 specimens belonging to 64 lichen species (Appendix 1) were collected directly by the author. Most of them belong to common and widespread species, and are not listed here. Only an account of the 28 species not reported for the study area in the floristic list by Valcuvia Passadore et al. (2002b) is given in detail.

Among these 28 species, $15(54 \%)$ are terricolous, 5 (18\%) epiphytic, $3(10,5 \%)$ lignicolous, $3(10,5 \%)$ saxicolous, $1(3,5 \%)$ epiphytic and lignicolous, 1 $(3,5 \%)$ terricolous and epiphytic. Among the epiphytic species, 3 were collected on Quercus robur, 2 on Pinus sp., 1 on Populus sp., 1 on Robinia pseudoacacia, 1 on Tilia sp.

\section{Athallia pyracea (Ach.) Arup, Frödén \& Søchting}

24: on bark of Populus sp. (GG). 25: on bark of Populus sp. (GG). 26: on bark of Populus sp. (GG). 27: on bark of Tilia sp. (GG).

The species occurs mainly on bark of Populus $s p$. in agricultural areas and of Tilia $s p$. in urbanized areas. It tolerates well eutrophication, and is rather frequent in mature poplar stands, in both the river valley and the main level of the plain in the surroundings (e.g. in the whole province of Pavia, pers. obs.).

\section{Cladonia caespiticia (Pers.) Flörke}

1: on organic soil at the base of Pinus sp. (GG). 5: on soil (GG). 7: on bark of Q. robur (GG). 8: on soil at the base of Calluna shrubs (GG). 12: on soil (GG).

The species can be terricolous on acidic organic soil and epiphytic on acidic bark, especially at the base of trunks, in dry grasslands, Calluna heathlands and mixed woods. It was not reported by Valcuvia Passadore et al. (2002b), even if it was listed in the checklist of the epiphytic lichens by Roella (1999). Uncommon, but probably also overlooked, especially in the northern part of the study area. 


\section{Cladonia cariosa (Ach.) Spreng.}

8: on acidic sandy-gravelly soil (GG; RA16). 12: on acidic soil (GG). 15: on acidic sandy-pebbly soil (GG; RA16).

Terricolous on sandy-gravelly and sandy-pebbly soil in pioneer or disturbed situations, in dry grasslands or at the edge of Calluna heathlands. Very rare, maybe also overlooked, it was probably more widespread in the past (cf. the record by Nocca \& Balbis (1823) for the countryside near Pavia).

\section{Cladonia cervicornis (Ach.) Flot.}

4: on soil (GG; GG15). 5: on soil (GG; GG15). 11: on soil (GG). 14: on soil (GG; GG15).

Terricolous on sandy-pebbly soil, in dry grasslands and Calluna heathlands. Very rare.

\section{Cladonia chlorophaea (Sommerf.) Spreng.}

4: on acidic sandy-pebbly soil (GG; GG15). 23: on acidic sandy-pebbly soil (GG; GG15).

Terricolous on sandy-pebbly soil in pioneer or disturbed situations, in dry grasslands and at the edge of trails. An overlooked species, probably more widespread. Without chemical analysis it can be easily confused with the morphologically similar Cladonia conista (which contains fumarprotocetraric and bourgeanic acid).

\section{Cladonia coccifera (L.) Willd.}

2: on acidic sandy-pebbly soil (GG). 3: on soil (GG; GG15). 4: on soil (GG; GG15). 5: on soil (GG; GG15). 6: on soil (GG; GG15). 8: on soil (GG; GG15). 10: on soil (GG; GG15). 11: on soil (GG; GG15). 12: on soil (GG; GG15). 14: on soil (GG; GG15). 17: on soil (GG; GG15). 18: on acidic sandy-pebbly soil (GG). 19: on acidic sandy-pebbly soil (GG).

Terricolous on sandy-pebbly and slightly humified soil. Rather widespread in dry habitats, mainly in the central and northern parts of the river valley.

\section{Cladonia conista (Nyl.) Robbins}

8: on sandy-pebbly soil (GG; GA18). 12: on sandypebbly soil (GG; GA18). 15: on sandy-pebbly soil (GG; GA18). 19: on sandy-pebbly soil (GG; GA18).

Terricolous on sandy-pebbly soil in pioneer or disturbed situations, in dry grasslands and open Calluna heathlands. An overlooked species, maybe more widespread, reported as new to Italy from 4 sites in the Ticino river valley by Gheza et al. (2018). Without chemical analysis it can be easily confused with the morphologically similar Cladonia chlorophaea (which contains only fumarprotocetraric acid).

\section{Cladonia digitata (L.) Hoffm.}

16: on several logs of Quercus robur (GG).

An epiphytic and lignicolous species found in only one site in the river valley. $C$. digitata is tipically found in higher altitudinal belts in Italy (Nimis, 2016) and is extremely rare in the Po Plain, where the only other record comes from an oak wood on the inland sand dunes of Cergnago, in the Eastern Lomellina (Gheza et al., 2015). It was found together with other lignicolous species: $\mathrm{Cla}$ - donia coniocraea (Flörke) Spreng., Cladonia fimbriata (L.) Fr. and, in one case only, C. floerkeana (see below). Extremely rare.

\section{Cladonia floerkeana (Fr.) Flörke}

16: on a single log of Quercus robur (GG).

As the previous species, $C$. floerkeana is an epiphytic and lignicolous species found in only one site in the river valley, on a single decorticated oak log in an open oak wood. Ecology and distribution in Italy are similar to those of $C$. digitata (Nimis, 2016), which was found on the same log as well. Extremely rare.

\section{Cladonia macilenta Hoffm.}

16: on several logs and stumps of Q. robur (GG). 19: on several logs and stumps of $Q$. robur (GG).

A mainly lignicolous species tipically found in higher altitudinal belts in Italy, as well as the two previous species. Extremely rare, but probably also overlooked, especially when sterile.

\section{Cladonia parasitica (Hoffm.) Hoffm.}

3: on organic soil on a stump (GG15). 16: on dead wood of $Q$. robur $(\mathrm{GG})$. 22: on dead wood of $Q$. robur $(\mathrm{GG})$. 23: on bark of $Q$. robur (GG15).

A mainly lignicolous species, found in deciduous oak woods on logs and snags. Extremely rare, but maybe also overlooked.

\section{Cladonia peziziformis (With.) J.R.Laundon (Fig. 1)}

8: on acidic sandy-pebbly soil (GG). 12: on acidic sandy-pebbly and slightly humified soil (GG; RA16).

Terricolous on sandy-pebbly or little humified soil in pioneer or disturbed situations, this species is easily outcompeted by mosses and vascular plants (Tønsberg \& Øvstedal, 1995) and therefore needs availability of open soil to persist. It was firstly reported by Gheza in Ravera et al. (2016) for one locality and then found, a little more widespread, in another locality. Extremely rare.

\section{Cladonia polycarpoides Nyl.}

2: on sandy-pebbly soil (GG; RA17a). 3: on sandypebbly soil (GG; RA17a). 4: on sandy-pebbly soil (GG; RA17a). 5: on sandy-pebbly soil (GG; RA17a). 6: on sandy-pebbly soil (GG; RA17a). 14: on sandy-pebbly soil (GG; RA17a). 15: on sandy-pebbly soil (GG). 17: on sandy-pebbly soil (GG; RA17a). 18: on sandy-pebbly soil (GG; RA17a). 19: on sandy-pebbly soil (GG; RA17a). 21: on sandy-pebbly soil (GG; RA17a).

Terricolous, generally found on sandy-pebbly soil in dry grasslands or even at the edge of Calluna heathlands. A thorough review of herbarium and newly collected specimens showed that the records of Cladonia subcervicornis (Vain.) Kernst. by Valcuvia Passadore et al. (2002a,b) and those of Cladonia symphycarpa (Flörke) Fr. by Gheza (2015) must be referred instead to this species. Rather common in dry grasslands.

\section{Cladonia portentosa (Dufour) Coem.}

5: on humified soil (GG). 6: on sandy-pebbly and humified soil (GG; GG15). 11: on sandy-pebbly and hu- 


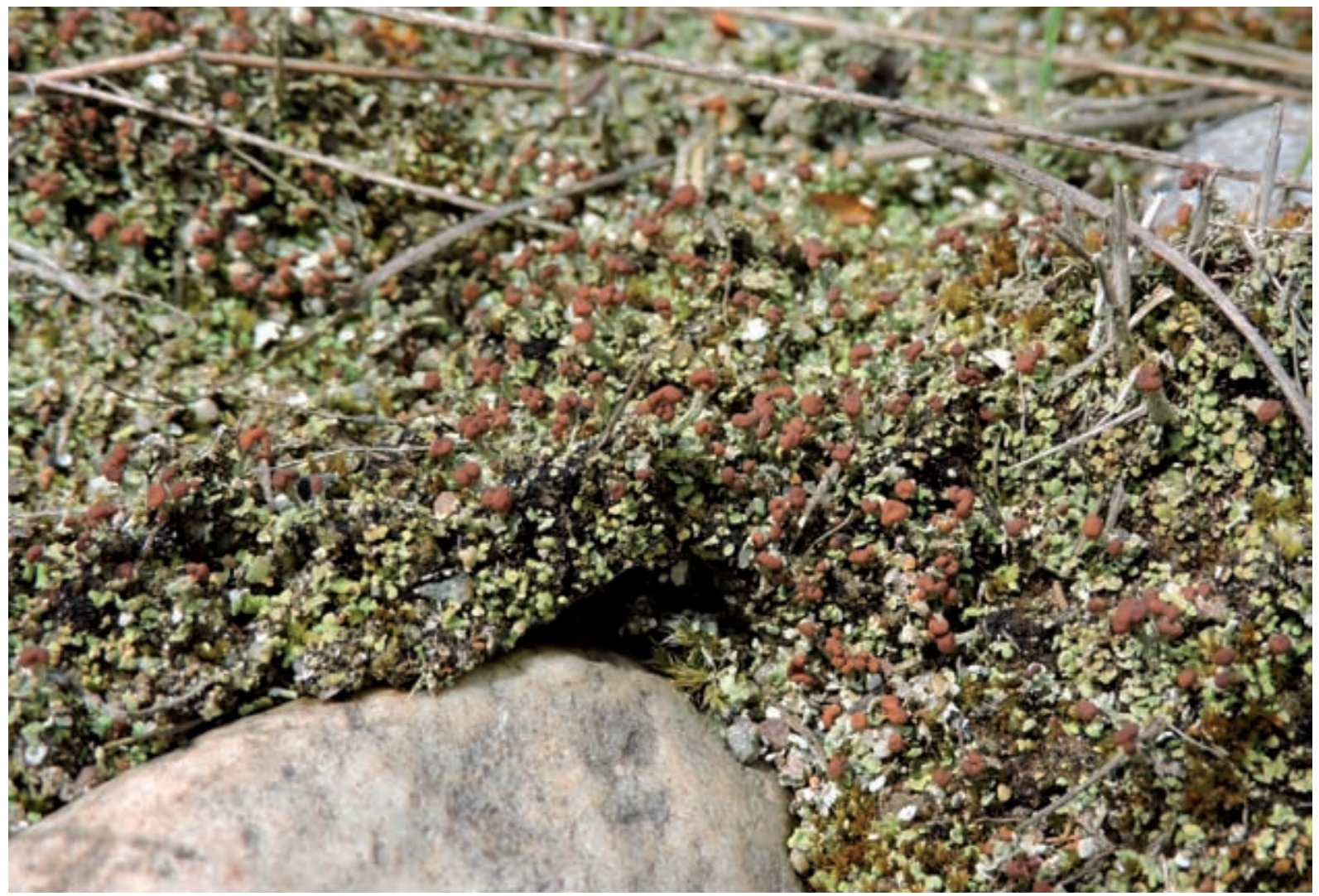

Fig. 1 - Cladonia peziziformis, Brughiera di Tornavento.

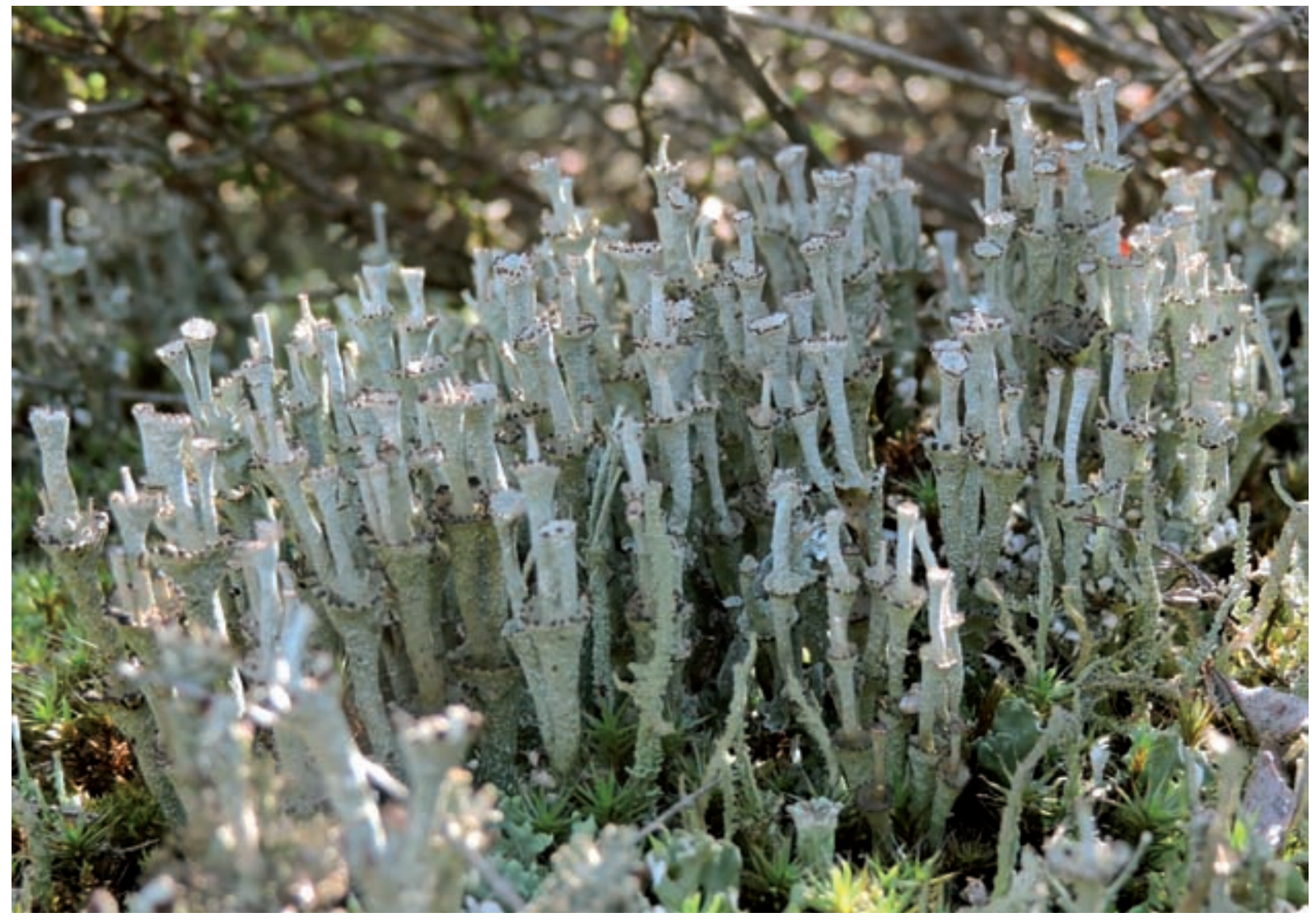

Fig. 2 - Cladonia verticillata, abandoned airfield "La Promessa". 
mified soil (GG). 14: on sandy-pebbly and humified soil (GG; GG15). 18: on sandy-pebbly and humified soil (GG; RA16). 19: on sandy-pebbly and humified soil (GG).

Terricolous, mostly found on evolved soils in thick lichen mats. The species was not reported for site 5 by Gheza (2015), but a deeper study of the area allowed to find several thalli in an undisturbed clearing in the wood near the dry grassland surveyed for that paper, together with two thalli of $C$. uncialis (see below). Sites 5 and 19 are the fourth and fifth occurrence sites of the species on the western side of the river valley (see Ravera et al. (2016) for an overview). The record from site 11 is the only one for the eastern side. Very rare.

\section{Cladonia pulvinata (Sandst.) Herk \& Aptroot}

8: on sandy-pebbly soil (GG; GA18). 11: on sandypebbly soil (GG; GA18). 12: on sandy-pebbly soil (GG; GA18).

Terricolous on sandy-pebbly or little humified soil in pioneer situations associated with open Calluna heathlands. It was reported as new to Italy from 5 sites in the Po Plain -3 of which are those cited here, located in the Ticino river valley and surrounding area - by Gheza et al. (2018). Extremely rare, perhaps more widespread in the past.

\section{Cladonia ramulosa (With.) J.R.Laundon}

23: on sandy-pebbly soil (GG; GG15).

Known only from one site, it was reported under " $\mathrm{Cla}$ donia sp." by Gheza (2015). Extremely rare.

\section{Cladonia rei Schaer.}

2: on soil (GG; GG15). 3: on soil (GG). 4: on soil (GG; GG15). 5: on soil (GG; GG15). 6: on soil (GG; GG15). 8: on soil (GG; GG15). 10: on soil (GG). 11: on soil (GG). 12: on soil (GG; GG15). 13: on soil (GG; GG15). 14: on soil (GG; GG15). 15: on soil (GG). 17: on soil (GG). 18: on soil (GG). 20: on soil (GG). 21: on soil (GG). 23: on soil (GG; GG15).

A terricolous species able to colonize different soil types. It is often found in disturbed situations, e.g. at the edge of footpaths and in dry grasslands, but it is also able to colonize wide areas under Calluna shrubs in mature dry heathlands. Rather common and widespread in dry habitats, probably overlooked in the past.

\section{Cladonia strepsilis (Ach.) Grognot}

4: on sandy-pebbly soil (GG; RA17b). 11: on soil (GG; RA17b). 14: on soil (GG; RA17b).

A terricolous species found in pioneer situations, typical of high altitude habitats in Italy (Nimis, 2016), exceptionally found in the Ticino river valley in recent years. Extremely rare, probably overlooked in the past.

\section{Cladonia uncialis (L.) F.H.Wigg.}

5: on organic soil (GG). 6: on organic soil (GG; GG15). 11: on sandy-pebbly soil $(\mathrm{GG})$. 14: on organic soil (GG; GG15).

The species was not reported for site 5 by Gheza (2015), but a deeper study of the area allowed to find two thalli in an undisturbed clearing in the wood near the dry grassland surveyed for that paper. This is the third record of the species on the western side of the river valley. The record from site 11 is the only one from the eastern side, and comes after a long time since the last record of the species in that area by Giacomini (1958). Extremely rare.

\section{Cladonia verticillata (Hoffm.) Schaer. (Fig. 2)}

11: on sandy-pebbly soil (GG).

A terricolous species which appears with very welldeveloped podetia in undisturbed but still open Calluna heathlands. The last known record of the species was that by Cozzi (1917) for the "Boscaccio di San Macario". Extremely rare.

\section{Coenogonium pineti (Ach.) Lücking \& Lumbsch}

7: on bark of $Q$.robur (GG).

An epiphytic species found in a very shaded broadleaf wood. It seems extremely rare, but it could be more widespread, especially in the northern part of the river valley.

\section{Dibaeis baeomyces (L.f.) Rambold \& Hertel}

8: on loamy soil (GG; RA17b).

A terricolous species typical of Calluna heathlands, found sterile in a single site. Reported by Biroli (1808) as common in heaths and by Cozzi (1917) for the heathlands near Gallarate, but not reported later neither by Giacomini (1958) nor by Valcuvia Passadore et al. (2002 b). Extremely rare, presently almost certainly limited to the locality reported here.

\section{Lecania turicensis (Hepp) Müll.Arg.}

On the statues in the Botanical Garden of Pavia (RI07).

A saxicolous species of basic substrates. Probably more widespread in the river valley, also - if not mainly - on human artifacts.

\section{Lepraria membranacea (Dicks.) Vain.}

9: on bark of R. pseudoacacia (GG).

Even if it is reported mainly as saxicolous, this species was found, in a single site, on the bark of several trees of $R$. pseudoacacia at the edge of a mixed deciduous wood. Extremely rare.

\section{Micarea prasina $\mathbf{F r}$.}

1: on bark of Pinus sp. (GG).

An epiphytic species found in a single site, in a shady mixed wood with pines and oaks. Extremely rare, perhaps more widespread at least in the northern part of the river valley.

\section{Normandina pulchella (Borrer) Nyl.}

1: on bark and logs of $Q$. robur (GG). 7: on bark of $Q$. robur (GG). 9: on bark of Q. robur (GG). 20: on bark of Q. $\operatorname{robur}(\mathrm{GG})$.

An epiphytic species generally found on epiphytic liverworts or mosses in shaded and humid situations, especially in open woods. The species was not reported by Valcuvia Passadore et al. (2002 b), but it was listed in the checklist of the epiphytic lichens by Roella (1999). It seems rather rare, but it is probably more widespread 
than found until now, especially in the northern part of the river valley.

\section{Sarcogyne regularis Körb.}

On the statues in the Botanical Garden of Pavia (RI07).

A saxicolous species of basic substrates. Probably more widespread in the river valley, especially on human artifacts.

\section{Verrucaria macrostoma DC.}

On the statues in the Botanical Garden of Pavia (RI07).

A saxicolous species of basic substrates. Probably more widespread in the river valley, mostly on human artifacts.

\section{CONCLUSIONS}

The number of lichen species known for the Ticino river valley has increased to 151 from the 123 reported by Valcuvia Passadore et al. (2002b). Other 19 species cited only in historical literature (Appendix 2) were not found during recent surveys, and could be considered as extinct in the river valley and its surroundings.

The great importance of the Ticino river valley and of the presence of two Parks protecting the whole rivercourse for the conservation of rare and endangered terricolous lichens was already highlighted by recent papers (Gheza, 2015; Gheza et al., 2018); the further, interesting new records reported in this contribution confirm the value of that area, not only for terricolous species.

The targeted researches carried out in dry grasslands, heathlands and oak woods resulted in the finding of several interesting species new to the study area, among which three which are rare nationwide (i.e. Cladonia peziziformis, $C$. portentosa, $C$. verticillata), five of particular biogeographical importance because usually limited to montane or alpine areas in Italy (i.e. Cladonia coccifera, C. digitata, C. floerkeana, C. strepsilis, C. uncialis) and even two new to Italy (i.e. Cladonia conista, C. pulvinata; Gheza et al., 2018). It is therefore probable that also other so far lichenologically overlooked habitats could host interesting species not yet recorded in the area (e.g. riparian woods, cf. Nascimbene et al., 2008).

\section{Acknowledgements}

I thank Dr. Valentina Parco and Dr. Silvia Nicola (Parco Naturale Lombardo della Valle del Ticino) and Dr. Gerolamo Boffino (Parco Naturale della Valle del Ticino Piemontese) for the authorizations to collect specimens; Dr. Juri Nascimbene (University of Bologna) and Prof. Helmut Mayrhofer (University of Graz) for their help in identifying some Cladonia specimens; Dr. Silvia Assini (University of Pavia) for her support to my lichenological researches; my friends Fabrizio Dell'Anna, Ester Gheza, Giacomo Rancati, Francesca Cassola, Andrea Oppi, Cristiano Papetti, Francesco Porro and Zeno Porro for fieldwork assistance in some occasions; the anonymous reviewer for useful remarks on the English style.

\section{REFERENCES}

Biroli G., 1808 - Flora Aconiensis, seu plantarum in novariensi provincia sponte nascentium descriptio. Typographia Viglevanensi, Vigevano.

Casarini P., Garavani M. \& Rolandi E., 1994 - Licheni epifiti per la valutazione dell'inquinamento atmosferico a Pavia. Ambiente Risorse Salute, 32: 28-31.

Casarini P., Genoni P. \& Roella V., 1995 - La qualità dell'aria nel Parco Regionale Lombardo della Valle del Ticino - monitoraggio dell'aria effettuato mediante analisi dei licheni. Consorzio Lombardo Parco della Valle del Ticino.

Cozzi C., 1917 - Manipolo di licheni della pianura milanese. Bullettino della Società Botanica Italiana, 1917 (4-5): 39-44.

D’Alessio D. \& Comolli R., 1996 - Progetto "Carta Pedologica - i suoli del Parco Ticino settore meridionale". Ente Regionale di Sviluppo Agricolo della Lombardia e Consorzio Parco Lombardo della Valle del Ticino, Milano.

Furlanetto D. (ed.), 2000 - Monitoraggio della qualità dell'aria mediante licheni nella Valle del Ticino. Consorzio Lombardo Parco della Valle del Ticino.

Furlanetto D. (ed.), 2002 - Atlante della Biodiversità nel Parco Ticino. Vol. 1: elenchi sistematici. Consorzio Lombardo Parco della Valle del Ticino.

Gheza G., 2015 - Terricolous lichens of the western Padanian Plain: new records of phytogeographical interest. Acta Botanica Gallica: Botany Letters, 162 (4): 339-348.

Gheza G., Assini S. \& Valcuvia Passadore M., 2015 Contribution to the knowledge of lichen flora of inland sand dunes in the western Po Plain (N Italy). Plant Biosystems, 149 (2): 307-314.

Gheza G., Assini S. \& Valcuvia Passadore M., 2016 - Terricolous lichen communities of Corynephorus canescens grasslands of Northern Italy. Tuexenia, 36: 121142.

Gheza G., Nascimbene J., Mayrhofer H., Barcella M. \& Assini S., 2018 - Two Cladonia species new to Italy from dry habitats in the Po Plain. Herzogia, 31 (1): 293-303.

Giacomini V., 1958 - Sulla vegetazione della brughiera di Gallarate. Archivio Botanico e Biogeografico Italiano, 34 (1-2): 63-68.

Nascimbene J., Marini L. \& Nimis P. L., 2008 - Epiphytic lichens in a riparian Natural Reserve of northern Italy: species richness, composition and conservation. Plant Biosystems, 142 (1): 94-98.

Nimis P. L., 2016 - The Lichens of Italy - a second annotated catalogue. Edizioni Università di Trieste.

Nocca D. \& Balbis G. B., 1823 - Flora Ticinensis. Volume II. Tipografia Capelli, Pavia.

Ravera S., Cogoni A., Totti C., Aleffi M., Assini S., Caporale S., Fackovcova Z., Filippino G., Gheza G., Olivieri N., Ottonello M., Paoli L., Poponessi A., Pisut I. \& Venanzoni R., 2016 - Notulae to the Italian flora of algae, bryophytes, fungi and lichens: 2. Italian Botanist, 2: 43-54.

Ravera S., Cogoni A., Vizzini A., Aleffi M., Assini S., Barcella M., Brackel W. von, Caporale S., Fackovcova 
Z., Filippino G., Gheza G., Gigante D., Paoli L., Potenza G., Poponessi S., Prosser F., Puntillo D., Puntillo M. \& Venanzoni R., 2017 a - Notulae to the Italian flora of algae, bryophytes, fungi and lichens: 3 . Italian Botanist, 3: 17-27.

Ravera S., Vizzini A., Cogoni A., Aleffi M., Assini S., Bergamo Decarli G., Bonini I., Brackel W. von, Cheli F., Darmostuk V., Fackovcova Z., Gavrylenko L., Gheza G., Guttova A., Mayrhofer H., Nascimbene J., Paoli L., Poponessi S., Prosser F., Puddu D., Puntillo D., Tatti A. \& Venanzoni R., 2017 b - Notulae to the Italian flora of algae, bryophytes, fungi and lichens: 4. Italian Botanist, 4: 73-86.

Rigamonti M., Altobelli E., Chiappetta D. \& Valcuvia Passadore M., 2007 - I licheni dei manufatti lapidei dell'Orto Botanico dell'Università di Pavia. XX Convegno della Società Lichenologica Italiana, Siena, 1314 settembre 2007, poster communication.

Rivas-Martìnez S., Penas A. \& Diaz T. E., 2004 - Biogeographic map of Europe - scale 1:16.000.000. Cartographic Service, University of Leòn, Spain. <http:// www.globalbioclimatics.org/form/maps.htm>

Roella V., 1999 - Licheni epifiti. In: Atlante della biodiversità nel Parco Ticino. Furlanetto D. (ed.). Consorzio Lombardo Parco della Valle del Ticino, Milano: 15-18.

Tønsberg T. \& Øvstedal D. O., 1995 - Cladonia peziziformis new to Norway from a burnt Calluna heath. Graphis scripta, 7: 11-12.

Valcuvia Passadore M., Brusa G., Chiappetta D., Delucchi C., Garavani M. \& Parco V., 2002 a - Licheni. In: Atlante della Biodiversità nel Parco Ticino. Vol. 1: elenchi sistematici. Furlanetto D. (ed). Consorzio Lombardo Parco della Valle del Ticino, Milano: 105127.

Valcuvia Passadore M., Brusa G., Chiappetta D., Delucchi C., Garavani M. \& Parco V., 2002 b - Licheni. In: Atlante della Biodiversità nel Parco Ticino. Vol. 2: monografie. Furlanetto D. (ed). Consorzio Lombardo Parco della Valle del Ticino, Milano: 7-44.

World Health Organization, 2016 - Global ambient air pollution. $<$ http://maps.who.int/airpollution>

\section{APPENDIX 1}

List of the 64 lichen species collected by the author in the Ticino river valley.

Amandinea punctata (Hoffm.) Coppins \& Scheid., Arthonia atra (Pers.) A.Schneid., Athallia pyracea (Ach.) Arup, Frödén \& Søchting, Caloplaca teicholyta (Ach.) J.Steiner, Candelaria concolor (Dicks.) Stein, Candelariella reflexa (Nyl.) Lettau, Candelariella xanthostigma (Ach.) Lettau, Cladonia caespiticia (Pers.) Flörke, Cladonia cariosa (Ach.) Spreng., Cladonia cervicornis (Ach.) Flot., Cladonia chlorophaea (Flörke ex Sommerf.) Spreng., Cladonia coccifera (L.) Willd., Cladonia coniocraea (Flörke) Spreng., Cladonia conista (Nyl.) Robbins, Cladonia digitata (L.) Hoffm., Cladonia fimbriata (L.) Fr., Cladonia floerkeana (Fr.) Flörke, Cladonia foliacea (Huds.) Willd., Cladonia furcata (Huds.) Schrad., Cladonia macilenta Hoffm., Cladonia parasitica (Hoffm.)
Hoffm., Cladonia peziziformis (With.) J.R.Laundon, Cladonia polycarpoides Nyl., Cladonia portentosa (Dufour) Coem., Cladonia pulvinata (Sandst.) Herk \& Aptroot, Cladonia pyxidata (L.) Hoffm., Cladonia ramulosa (With.) J.R.Laundon, Cladonia rangiformis Hoffm., Cladonia rei Schaer., Cladonia squamosa Hoffm., Cladonia strepsilis (Ach.) Grognot, Cladonia uncialis (L.) F.H.Wigg., Cladonia verticillata (Hoffm.) Schaer., Coenogonium pineti (Ach.) Lücking \& Lumbsch, Dibaeis baeomyces (L.f.) Rambold \& Hertel, Evernia prunastri (L.) Ach., Flavoparmelia caperata (L.) Hale, Flavoplaca citrina (Hoffm.) Arup, Frödén \& Søchting, Graphis scripta (L.) Ach., Hypocenomyce scalaris (Ach.) M.Choisy, Hypogymnia physodes (L.) Nyl., Lecania cyrtella (Ach.) Th.Fr., Lecanora campestris (Schaer.) Hue, Lecanora carpinea (L.) Vain., Lecanora chlarotera Nyl., Lecidella elaeochroma (Ach.) M.Choisy, Lepraria incana (L.) Ach., Lepraria membranacea (Dicks.) Vain., Micarea prasina Fr., Myriolecis hagenii (Ach.) Śliwa, Zhao Xin \& Lumbsch, Normandina pulchella (Borrer) Nyl., Parmelina tiliacea (Hoffm.) Hale, Parmotrema perlatum (Huds.) M.Choisy, Phaeophyscia orbicularis (Neck.) Moberg, Physcia adscendens H.Olivier, Physcia tenella (Scop.) DC, Physconia grisea (Lam.) Poelt, Protoparmeliopsis muralis (Schreb.) M.Choisy, Punctelia subrudecta (Nyl.) Krog, Verrucaria nigrescens Pers., Xanthomendoza huculica (S.Y.Kondr.) Diederich, Xanthoparmelia conspersa (Ach.) Hale, Xanthoparmelia pulla (Ach). O.Blanco, A.Crespo, Elix, D.Hawksw. \& Lumbsch, Xanthoria parietina (L.) Th.Fr.

\section{APPENDIX 2}

List of the 19 lichen species reported in historical literature (Biroli, 1808; Cozzi, 1917; Giacomini, 1958) not found during recent surveys in the Ticino river valley.

Alyxoria varia (Pers.) Ertz \& Tehler (C17), Anaptychia ciliaris (L.) A.Massal. (C17), Arthonia galactites (DC.) Dufour (C17), Baeomyces rufus (Huds.) Rebent. (B08), Cetraria aculeata (Schreb.) Fr. (B08), Cetraria islandica (L.) Ach. (B08), Chaenotheca hispidula (Ach.) Zahlbr. (B08), Cladonia amaurocraea (Flörke) Schaer. (G58), Cladonia arbuscula (Wallr.) Flot. (B08; G58), Cladonia gracilis (L.) Willd. (G58), Cladonia pleurota (Flörke) Schaer. (G58), Collema nigrescens (Huds.) DC. (C17), Lecanora varia (Hoffm.) Ach. (C17), Leptogium hildenbrandii (Garov.) Nyl. (C17), Peltigera canina (L.) Willd. (C17), Pseudoschismatomma rufescens (Pers.) Ertz \& Tehler (C17), Physcia leptalea (Ach.) DC. (C17), Physcia stellaris (L.) Nyl. (C17), Usnea dasopoga (Ach.) Nyl. (C17). 